\title{
Comparative Studies of Membrane Distillation and Reverse Osmosis for Seawater Desalination
}

\author{
Hilal M. Al Maawali ${ }^{1}$, Jihan S. Al-Qartoubi ${ }^{1}$, Maryam S. Al Maamari ${ }^{1}$, Reem K. Al \\ Balushi ${ }^{1}$, Rudayna A. Al Mazrui ${ }^{1}$, Asma S. Al Kharusi ${ }^{1}$, Jimoh K. Adewole ${ }^{1}$ \\ ${ }^{1}$ Department of Process Engineering, International Maritime College, Sultanate of Oman \\ Corresponding author (Dr. Jimoh K. Adewole): jimoh@imco.edu.om \\ DOI: https://doi.org/10.47611/jsr.v10i2.1208
}

\begin{abstract}
$\underline{\text { ABSTRACT }}$
The essence of water in our everyday activities cannot be overemphasized. The major source of water in the Middle East is the seawater and the most widely used technique for water treatment is the Reverse osmosis (RO). However, the major challenge in the use of RO is the high-energy consumption resulting from the need for pumping at very high pressure. In this research work, the capability of a low-pressure Membrane Distillation (MD) technique as a replacement for RO was evaluated. A comparative study of MD and RO was done using process intensification, cost estimation and process economic approach. The study was performed using process intensification metrics including mass intensity; waste intensity; productivity/size ratio; productivity/weight ratio; flexibility and modularity. The cost estimation involving the capital and operating expenses for RO and MD desalination plants was also determined based on the productivity of the plants. Moreover, process economic factors including profits, cash flow and cumulative cash flow were also evaluated. The preliminary results obtained showed that the MD and RO possess same capability to be used in the desalination plant based on process intensification. In addition, MD can be preferred in a situation where waste heat can be harnessed from neighbouring industries. MD can also be better than RO with respect to resistance of MD membrane materials to fouling. On the other hand, MD is more expensive than RO based on cost estimation and process economic results obtained.
\end{abstract}

\section{Introduction}

At the present, the evaluation of the performance of the RO and the MD depends in several metrics for seawater desalination. Commonly used metrics have focused on membrane materials, membrane modules, and the entire plant. Process Intensification approach involved the use of metrics such mass intensity, waste intensity, productivity/size ratio, productivity/weight ratio, flexibility, and modularity for evaluating the performance of processes. Using these metrics, industrial processes can be redesigned to improve the production capacities, and level of safety, and reduce the raw material consumption, energy utilization, equipment size and waste production.

\section{Methodology}

Mass intensity is one of the metrics that affect the performance of RO and MD. It means the ratio of the total mass of feed used in the process to mass of the production. While the mass intensity ratio means the mass intensity of 
membrane to mass intensity of traditional. According Constable et al., (2002), the mass intensity and mass intensity ratio can be calculated by using the equations below:

$$
\begin{aligned}
& \text { Eq. } 1 \text { Mass intensity }=\frac{\text { Total mass used in the process }(\mathrm{kg})}{\text { Mass of the product }} \\
& \text { Eq. 1. } 1 \text { Mass intensity ratio }=\frac{\text { Mass intensity(Membranes) }}{\text { Mass intensity(Traditional) }}
\end{aligned}
$$

The second metric that can be used in evaluating the performance of RO and MD is waste intensity. It means the quantity of waste product that is manufactured by a particular process regarding the quantity of input materials. The purpose of waste intensity is to produce less waste from input materials. Waste intensity ratio means the waste intensity of membrane to waste intensity of traditional process as stated by Drioli et al., (2017), It can be calculated by below equation:

$$
\begin{gathered}
\text { Eq. } 2 \text { Waste intensity }=\frac{\text { Total waste }(\mathrm{kg})}{\text { Mass of product }(\mathrm{kg})} \\
\text { Eq. 2.1 Waste intensity ratio }=\frac{\text { Waste intensity (Membranes) }}{\text { Waste intensity (Traditional) }}
\end{gathered}
$$

Productivity / size ratio is the third metric that affects directly in the evaluating the performance of RO and MD. It compares the ratio of productivity / size ratio of membrane with the traditional operation. For that reason, when productivity/size ratio greater than one, membrane operations should be chosen, while, for when productivity/size values lesser than one, traditional units should be selected Criscuoli et al., (2007). As shows in the below equation:

$$
\text { Eq. } 3 \text { Productivity } / \text { size ratio }=\frac{P / \operatorname{size}(\text { Membrane })}{P / \operatorname{size}(\text { Traditional })}
$$

The fourth metric that influences directly in the evaluating the performance of RO and MD is the productivity / weight ratio. It is very significant to the location of plant installation. If the plant located in offshore or in remote areas. It compares the productivity/weight ratio with the conventional system. Therefore, the productivity/weight ratio greater than one is in favour of membranes, while the productivity/weight ratio minor than one means the traditional systems are performing well (Drioli et al., (2017). In addition, it can be calculated as below equation:

$$
\text { Eq. } 4 \text { Productivity } / \text { weight ratio }=\frac{\mathrm{P} / \text { weight }(\text { Membrane })}{\mathrm{P} / \text { weight }(\text { Traditional })}
$$

Flexibility is the fifth metric that affects directly in the evaluating the performance of RO and MD. It means the ability to handle the number of processes perfumed and modifications that may occur during the lifetime of the plant. It aims to reduce the costs that related to changes or variations of the current operating units. Also, variation handled by membrane compare with variation handled of traditional. If the flexibility of the membrane more than one as previous metrics, membrane is preferred as said by Criscuoli et al., (2007). It can be found by below equations:

$$
\begin{gathered}
\text { Eq. } 5 \text { Flexibility }=\frac{\text { Variation handled(Membrane) }}{\text { Variation handled (Traditional) }} \\
\text { Eq. 5. } 1 \text { Flexibility }=\frac{N_{\text {processes performed }(\text { Membrane })}}{N_{\text {processes performed }} \text { (Traditional) }}
\end{gathered}
$$

The sixth metric that influences directly on the evaluating the performance of RO and MD is modularity. It reflects changes in the plant size compared to the productivity. The modularity metric should also be greater than one for a membrane plant to be favoured as consistent with (Drioli et al., 2017). It can be calculated by below equation:

$$
\text { Eq. } 6 \text { Modularity }=\frac{\left|\frac{\text { area2 }}{\text { area1 }}-\frac{\text { productivity2 }}{\text { productivity1 } \mid}\right| \text { (Membranes) }}{\left|\frac{\text { area2 }}{\text { area1 }}-\frac{\text { productivity2 }}{\text { productivity1 } 1}\right| \text { (Tradtinal) }}
$$

By previous metrics, the evaluation of performance of the RO and the MD seawater desalination can be found by using the previous equations. All these metrics should be higher than one for MD to be preferred in the plant. That 
means the perfect performance of RO and MD for desalinating seawater when the results of the metrics of MD greater than the result of RO. Also, the unit that has low cost and with high profit is preferred in the plant.

\section{Unit operation and productivity values}

Regarding to productivity/ size ratio and productivity/ weight ratio metrics, we provided values required to calculate the metrics for RO and MD unit as shows in below tables.

Table 1 Operating and designing condition of RO and MD.

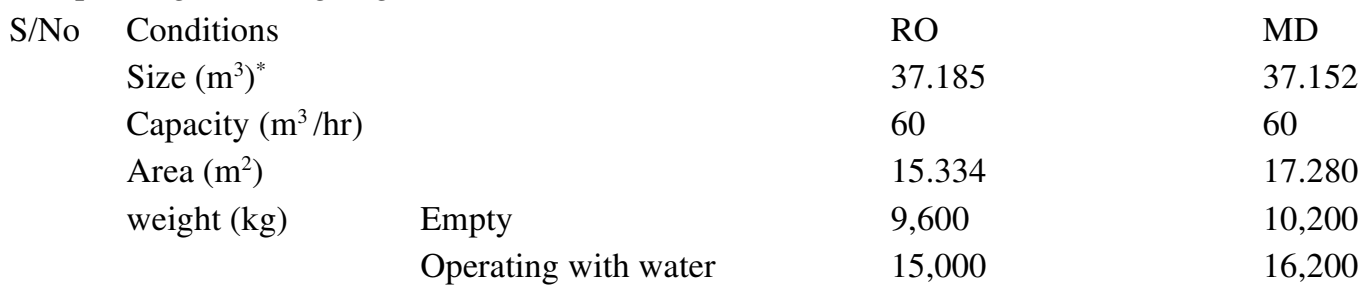

"Size of RO unit is $1.87 \mathrm{~W} \times 8.2 \mathrm{~L} \times 2.425 \mathrm{H}$ in meter.

*Size of MD unit is $3.60 \mathrm{~L} \times 0.80 \mathrm{~W} \times 2.15 \mathrm{H}$ in meter.

The data used for MD were obtained from MD module with lower capacity than RO. For of this reason, some scaleup calculations were performed to equate the MD data to that of RO. These calculations were performed based on the assumption of a linear relationship between the original MD data and the calculated data.

\section{Feed stream properties}

The table below shows the values of feed stream (which is seawater) as stated by Sharqiyah, (2005) and Serve et al., (2015), and the operating values as stated by T.K.KIM, (2013). It should be noted that the values of feed stream properties were taken from two sources (Oman Sea and Indian Ocean).

Table 2 Feed stream properties

$\begin{array}{lll}\text { S/No } & \text { Feed Stream } & \text { Values } \\ \text { 1. } & \text { Feed flowrate } & 60 \mathrm{~m}^{3} / \mathrm{hr} \\ 2 . & \text { Feed temperature } & 37{ }^{\circ} \mathrm{C} \\ 3 . & \text { Feed pressure } & 1 \mathrm{bar} \\ 4 . & \text { TDS } & 39,700 \mathrm{mg} / \mathrm{l} \\ 5 . & \text { BOD } & 50 \mathrm{mg} / \mathrm{L} \\ 6 . & \text { COD } & 170 \mathrm{mg} / \mathrm{L} \\ 7 . & \mathrm{pH} & 7.5 \\ 8 . & \text { Turbidity } & 170 \mathrm{NTU} \\ 9 . & \text { Concentration of } \mathrm{Na}^{+} & 13,912 \mathrm{mg} / 1 \\ 10 . & \text { Concentration of } \mathrm{Ca}^{+} \text {or } \mathrm{CaCO}_{3} & 108 \mathrm{mg} / 1 \\ 11 . & \text { Concentration of } \mathrm{K}^{+} & 531 \mathrm{mg} / 1 \\ 12 . & \text { Concentration of } \mathrm{Mg}^{+} & 1776 \mathrm{mg} / 1\end{array}$




\section{Results and Discussion}

The performance of RO and MD for seawater desalination was evaluated using process intensification metrics including mass intensity, waste intensity, productivity/size ratio, productivity/weight ratio, flexibility, and modularity. Also, compare between RO and MD by using cost estimation and process economic. All data required are shown in tables in data collection.

\section{Target production stream properties}

The below table shows that the target stream properties values which were obtained from T.K.KIM, (2013). Other values obtained from PDO, (2012). Regarding to Oman standard for non-potable water, the TDS should be less than $500 \mathrm{mg} / \mathrm{L}$, COD should be less than $200 \mathrm{mg} / \mathrm{L}$, the concentration of $\mathrm{Ca}+$ or CaCO3 should be between $45-170 \mathrm{mg} / \mathrm{L}$ and the concentration of $\mathrm{Mg}+$ is depended on the concentration of sulphites. If the concentration of sulphites equal to $30 \mathrm{mg} / \mathrm{L}$, the concentration of $\mathrm{Mg}+$ should be more than $250 \mathrm{mg} / \mathrm{L}$. While if the concentration of sulphites equal to $150 \mathrm{mg} / \mathrm{L}$, the concentration of $\mathrm{Mg}+$ should be less than $250 \mathrm{mg} / \mathrm{L}$.

Table 3 Target production stream properties

$\begin{array}{lll}\text { S/No } & \text { Target production Stream } & \text { Values } \\ \text { 1. } & \text { Production flowrate } & 60 \mathrm{~m}^{3} / \mathrm{hr} \\ 2 . & \text { Temperature } & 37{ }^{\circ} \mathrm{C} \\ \text { 3. } & \text { Pressure } & 5 \mathrm{bar} \\ \text { 4. } & \text { TDS } & <500 \mathrm{mg} / \mathrm{L} \\ 5 . & \text { BOD } & 20 \mathrm{mg} / \mathrm{L} \\ 6 . & \text { COD } & <200 \mathrm{mg} / \mathrm{L} \\ \text { 7. } & \text { pH } & 6.5-8.5 \\ 8 . & \text { Turbidity } & <1.0 \mathrm{NTU} \\ \text { 9. } & \text { Concentration of } \mathrm{Na}^{+} & <200-400 \mathrm{mg} / \mathrm{L} \\ 10 . & \text { Concentration of } \mathrm{Ca}^{+} \text {or } \mathrm{CaCO}_{3} & 45-170 \mathrm{mg} / \mathrm{L} \\ 11 . & \text { Concentration of } \mathrm{K}^{+} & \mathrm{Less} \text { than } 50 \mathrm{mg} / \mathrm{L} \\ 12 . & \text { Concentration of } \mathrm{Mg}^{+} & 30 \text { if sulphites }>250 \mathrm{mg} / \mathrm{L} \\ & & 150 \text { if sulphites }<250 \mathrm{mg} / \mathrm{L}\end{array}$

\section{Production properties and Operating conditions of RO}

As stated by T.K.KIM, (2013) 'the SWRO system consisted of 17 vessels and each vessel has 7 membranes and the operating values of product from RO unit as shows in the below table as according to T.K.KIM, (2013).While other values as stated by (Anon, 1996). Accordingly, the temperature of the production was taken as the normal weather temperature. Also, regarding production properties, the TDS should be less than $400 \mathrm{mg} / \mathrm{L}$ and the concentration of $\mathrm{K}+$ less than $50 \mathrm{mg} / \mathrm{L}$. Also, the operating pressure is very high because the working principle of RO depended on high pressure for operating salts from seawater. 
Table 4 Production properties and Operating conditions of RO

$\begin{array}{lll}\text { S/No } & \text { Product or exit stream from RO unit } & \text { Values } \\ 1 . & \text { Productivity flow rate } & 60 \mathrm{~m}^{3} / \mathrm{hr} \\ 2 . & \text { Temperature } & 37{ }^{\circ} \mathrm{C} \\ 3 . & \text { Pressure } & 63 \mathrm{bar} \\ 4 . & \text { TDS } & <400 \mathrm{mg} / \mathrm{L} \\ 5 . & \text { BOD } & 0.73 \mathrm{mg} / \mathrm{L} \\ 6 . & \text { COD } & 2.9 \mathrm{mg} / \mathrm{L} \\ 7 . & \text { pH } & 7-8.5 \\ 8 . & \text { Turbidity } & 0.6 \mathrm{NTU} \\ 9 . & \text { Concentration of } \mathrm{Na}+ & 50 \mathrm{mg} / \mathrm{L} \\ 10 . & \text { Concentration of } \mathrm{Ca}+\text { or } \mathrm{CaCO} 3 & 11 \mathrm{mg} / \mathrm{L} \\ 11 . & \text { Concentration of } \mathrm{K}+ & <50 \mathrm{mg} / \mathrm{L} \\ 12 & \text { Concentration of } \mathrm{Mg}+ & 55 \mathrm{mg} / \mathrm{L}\end{array}$

\section{Production properties and operating condition of MD}

According to Dijkstra, J. (2019) the DCMD system which is a type of MD. It consisted of 3 pallets and 6 modules. The unit capacity is approximately $10 \mathrm{~m}^{3} / \mathrm{hr}$ distillate every day from seawater and based on the assumption taking in table 4.7 that means 6 units will produce 10 then the total is $60 \mathrm{~m}^{3} / \mathrm{hr}$ productivity.

The below table shows most of values of the product stream from the MD unit as stated by Dijkstra,(2020). While the other values as stead by Fard et al., (2014) in the different experiments of DCMD for testing pure water quality produced from seawater with salt rejection $<99.99 \%$. Also, regarding to Aydiner et al., (2017) "the values of TOC and DOC was finding by experiment where the TOC was equal to $0.08 \mathrm{mg} / \mathrm{L}$ while the DOC was equal to $0.06 \mathrm{mg} / \mathrm{L}$ ". So according to the previous experiment, we ratiocinate the values of BOD and COD are close to zero.

Table 5 Production properties and operating condition of MD

$\begin{array}{lll}\text { S/No } & \text { Product or exit stream from MD unit } & \text { Values } \\ \text { 1. } & \text { Productivity flowrate } & 60 \mathrm{~m}^{3} / \mathrm{hr} \\ 2 . & \text { temperature } & 70-90^{\circ} \mathrm{C} \\ \text { 3. } & \text { pressure } & 1 \mathrm{bar} \\ \text { 4. } & \text { TDS } & 2.69 \mathrm{mg} / \mathrm{L} \\ 5 . & \text { BOD } & \text { Approx. zero } \\ 6 . & \text { COD } & \text { Approx. zero } \\ 7 . & \text { pH } & 7-8.5 \\ 8 . & \text { Turbidity } & <1 \mathrm{NTU} \\ 9 . & \text { Concentration of } \mathrm{Na}^{+} & 0.8 \mathrm{mg} / \mathrm{L} \\ 10 . & \text { Concentration of } \mathrm{Ca}^{+} \text {or } \mathrm{CaCO}_{3} & <0.1 \mathrm{mg} / \mathrm{L} \\ 11- & \text { Concentration of } \mathrm{K}^{+} & <0.1 \mathrm{mg} / \mathrm{L} \\ 12- & \text { Concentration of } \mathrm{Mg}^{+} & 55 \mathrm{mg} / \mathrm{L}\end{array}$

\section{Salt rejection information}

Referring to Fard et al., (2014), the value of salt rejection percentage for MD as shown in below table. While the value of salt rejection percentage for RO as stead by DuPont, (2020) as seen in below table: 
Table 6 Salt rejection on RO and MD

$\begin{array}{llll}\text { S/No } & \text { Salt rejection on each unit operation } & \text { Membrane types } & \text { Percentage } \\ 1 . & \text { RO } & \text { SW30XLE-400 } & 99.8 \% \\ 2 . & \text { MD } & \text { PTFE } & 99.99 \%\end{array}$

Waste and mass production information

\section{Material Balance Calculations for RO}

Regarding to waste intensity metric, we calculated the material balance of exit steam units as the waste (R) and product (P) production.

We calculate the material balance of RO unit to find out the product $(\mathrm{P})$ and waste $(\mathrm{R})$ volumetric flow rate by using below figure and material balance equation.

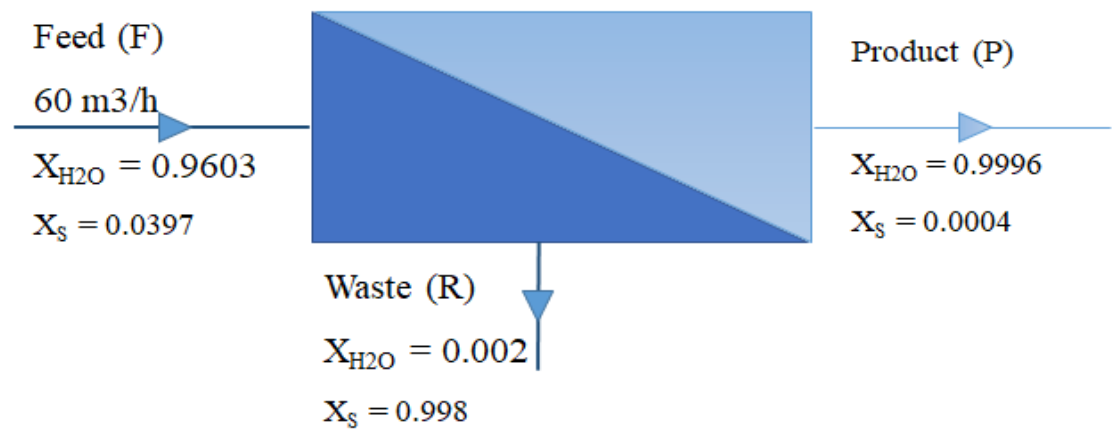

Figure 4.3 Sketch of block diagram of RO (IMCO Students, 2020).

Eq. 7 Overall $\mathrm{M}$. $\mathrm{B} \rightarrow \mathrm{F}=\mathrm{P}+\mathrm{R}$

$$
\begin{aligned}
60 & =\mathrm{P}+\mathrm{R} \\
60-\mathrm{P} & =\mathrm{R} \rightarrow(1.1)
\end{aligned}
$$

Eq. 7. 1 Compound M. $B\left(\mathrm{H}_{2} \mathrm{O}\right) \rightarrow$ F. $X_{F}=$ P. $X_{P}+$ R. $X_{R}$

$$
\begin{gathered}
(60 \times 0.9603)=\mathrm{P}(0.9996)+\mathrm{R}(0.002) \\
(57.618)-\left(2 \times 10^{-3}\right) \mathrm{R}=\mathrm{P} \rightarrow(2.1)
\end{gathered}
$$

By using eq (1.1) sub in eq (2.1)

$$
\begin{gathered}
(57.618)-\left(\left(2 \times 10^{-3}\right) \times(60-\mathrm{P})\right)=\mathrm{P} \\
\mathrm{P}=57.636 \mathrm{~m}^{3} / \mathrm{hr} \rightarrow(2.2)
\end{gathered}
$$

By using eq (2.2) sub in eq(1.1)

$$
\begin{gathered}
\mathrm{R}=60-\mathrm{P} \\
\mathrm{R}=60-57.636=2.364 \mathrm{~m}^{3} / \mathrm{hr}
\end{gathered}
$$

Material Balance Calculations for MD:

On waste intensity metric, we calculated the material balance of exit steam units as the waste $(\mathrm{R})$ and product $(\mathrm{P})$ production. 
We calculate the material balance of the MD unit to find out the product $(\mathrm{P})$ and waste $(\mathrm{R})$ volumetric flow rate by

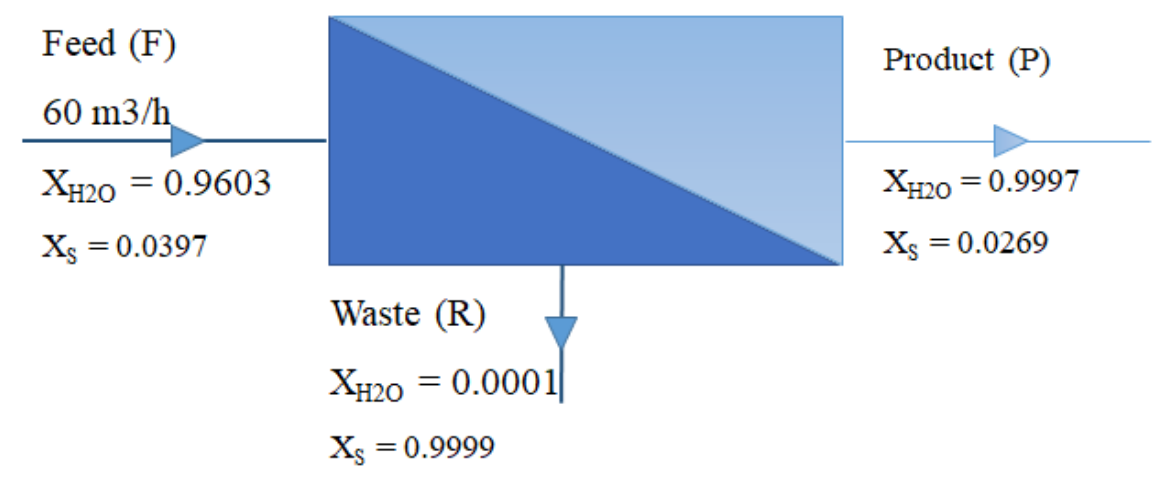
using below figure and material balance equation.

Figure 4.4 MD sketch of block diagram of MD

$$
\begin{gathered}
\text { Eq. 7 Overall Material Balance } \rightarrow \mathrm{F}=\mathrm{P}+\mathrm{R} \\
60=\mathrm{P}+\mathrm{R} \\
60-\mathrm{P}=\mathrm{R} \rightarrow(1.1) \\
\begin{array}{c}
\text { Eq. 7. 1 Component Material Balance }\left(\mathrm{H}_{2} \mathrm{O}\right) \rightarrow \mathrm{F} . \mathrm{X}_{\mathrm{F}}=\mathrm{P} . \mathrm{X}_{\mathrm{P}}+\mathrm{R} . \mathrm{X}_{\mathrm{R}} \\
60 \times 0.9603=\mathrm{P}(0.9997)+\mathrm{R}(0.0001) \\
57.635-\left(1 \times 10^{-4} \mathrm{R}\right)=(0.9997) \mathrm{P} \rightarrow(2.1) \\
\text { By using eq }(1.1) \text { sub in eq }(2.1) \\
57.635-\left(\left(1 \times 10^{-4}\right) \times(60-\mathrm{P})\right)=(0.9997) \mathrm{P} \\
\mathrm{P}=57.623 \mathrm{~m}^{3} / \mathrm{hr} \rightarrow(2.2) \\
\text { By using eq (2.2) sub in eq(1.1), } \mathrm{R}=60-\mathrm{P} \\
\mathrm{R}=60-57.623=2.377 \mathrm{~m}^{3} / \mathrm{hr}
\end{array}
\end{gathered}
$$

\begin{tabular}{|c|c|c|c|}
\hline S/No & $\begin{array}{l}\text { Name of } \\
\text { unit }\end{array}$ & $\begin{array}{l}\text { Product production (permeate) in } \\
\left(\mathrm{m}^{3} / \mathrm{hr}\right)\end{array}$ & $\begin{array}{l}\text { Waste production (rejected wa- } \\
\text { ter) in }\left(\mathrm{m}^{3} / \mathrm{hr}\right)\end{array}$ \\
\hline 1. & RO & 57.636 & 2.364 \\
\hline 2. & MD & 57.635 & 2.365 \\
\hline
\end{tabular}

Table 7 Waste production (rejected water) and Product production (permeate) from RO and MD.

\section{Variations in the Plant Size Vs Variation of the Productivity:}

Concerning to modularity metric, we calculated the area of RO system and area of the MD system for treating different values of productivity to calculate the metric.

For treating $60 \mathrm{~m}^{3} / \mathrm{hr}$, the area of RO system was $15.334 \mathrm{~m}^{2}$ while area of MD system was $17.280 \mathrm{~m}^{2}$. If we increase the productivity of the unit for treating $600 \mathrm{~m}^{3} / \mathrm{hr}$, what will be the area of the RO unit and area of MD unit? $\mathrm{RO}_{\text {Area }}=$ $\left((9200.4 \mathrm{~m} / \mathrm{hr}) \div\left(60 \mathrm{~m}^{3} / \mathrm{hr}\right)\right)=153.340 \mathrm{~m}^{2} . \mathrm{MD}_{\text {Area }}=\left((10368 \mathrm{~m} / \mathrm{hr}) \div\left(60 \mathrm{~m}^{3} / \mathrm{hr}\right)\right)=172.80 \mathrm{~m}^{2}$.

Table 8 Variations in the Plant Size Vs Variation of the Productivity

$\begin{array}{llll}\text { S/No } & \text { Productivity } & \text { Area of RO unit }\left(\mathrm{m}^{2}\right) & \text { Area of MD unit }\left(\mathrm{m}^{2}\right) \\ 1 . & \text { For treating } 60 \mathrm{~m}^{3} / \mathrm{h} & 15.334 & 17.280 \\ 2 . & \text { For treating } 600 \mathrm{~m}^{3} / \mathrm{h} & 153.340 & 172.80\end{array}$




\section{Variations in the Operating Conditions Considered}

Regarding to flexibility metric, we calculated operating conditions considered by subtracting minimum values of variations can be handled by the RO and MD unit from maximum values of variations. As below table shows the range of variation values can be handled by RO and MD as according to T.K.Kim et al,(2013) and Dijkstra,(2020).

Table 9 The range of variation values can be handled by RO and MD

$\begin{array}{llll}\text { S/No } & \text { Variations } & \text { RO } & \text { MD } \\ 1 . & \text { Feed composition by using TDS } & 0.02-39260 \mathrm{mg} / \mathrm{L} & 0.01-50000 \mathrm{mg} / \mathrm{L} \\ 2 . & \text { Pressure } & 52-63 \mathrm{bar} & 0.1-1 \mathrm{bar} \\ 3 . & \text { Temperature } & 20-37^{\circ} \mathrm{C} & 70-90^{\circ} \mathrm{C}\end{array}$

By subtracting the minimum values of variations from maximum variations values can be handled by the RO and MD unit. The below table shows variations in the operating conditions considered.

Table 10 Variations in the Operating Conditions Considered

$\begin{array}{llll}\text { SI.NO. } & \text { Variations } & \text { RO } & \text { MD } \\ 1 . & \text { Feed composition by using TDS. } & 39259.98 \mathrm{mg} / \mathrm{L} & 49999.99 \mathrm{mg} / \mathrm{L} \\ \text { 2. } & \text { Pressure } & 11 \mathrm{bar} & 0.9 \mathrm{bar} \\ 3 . & \text { Temperature } & 17^{\circ} \mathrm{C} & 20^{\circ} \mathrm{C}\end{array}$

\section{Data Analysis of metrics calculation:}

The mass and waste intensity were calculated for RO and MD units using the steps stated below and by using values as stated in table 7 and the feed flowrate value which is $60 \mathrm{~m}^{3} / \mathrm{hr}$. Based on the results of mass and waste intensity, the mass and waste intensity ratio were calculated. Therefore, the result of mass intensity ratio is less than 1 and that means the MD is not preferred than RO in the desalination plant. The results of waste intensity ratio showed a value less than 1 and that means the RO is preferred than MD in the desalination plant. The productivity/size ratio was estimated by using the data given for RO and MD unit as table 1 . The result of productivity/size ratio showed a value that is more than 1 and that means the MD is preferred than RO in the desalination plant. The productivity/weight ratio intensity obtained by using below steps using the data given for RO and MD unit as stated in table 1 under operating with water. The result of the productivity/weight ratio is less than 1 and that means the RO is preferred than MD in the desalination plant.

The flexibility was calculated using the steps below and by including variations in the operating conditions considered for RO and MD unit using the values stated in tables 4 and 5. The result of flexibility by using pressure showed a value less than 1 and that means the MD is not preferred than $\mathrm{RO}$ in the desalination plant. Regarding to temperature handled by the RO and MD unit, the flexibility metric was calculated. The flexibility by using temperature showed a value higher than 1 and that means the MD is preferred than RO in the desalination plant. According to feed compositions, the flexibility metric was calculated by using the TDS of feed composition. Therefore, the result of flexibility by using TDS showed a value that is more than 1 and that means the MD is preferred than RO in the desalination plant. Moreover, the flexibility was calculated by including number of processes performed by RO and MD unit. Where, the MD can handle two processes such as high pressure and high temperature while RO can handle only highpressure process. The flexibility by using number of processes performed equalled to more than one and that means the MD is preferred than RO in the desalination plant.

The modularity metric was calculated by using steps below. The data given for areas and productivities of RO and MD units were stated in table 8 . Subsequently, the result of modularity showed a value equal to 0 and that means the $\mathrm{MD}$ is not preferred than $\mathrm{RO}$ in the desalination plant. According to process intensification metrics calculations, table 11 indicates adopted results for RO and MD desalination plant. 
Total mass used in the process $(\mathrm{kg})=60000 \mathrm{~kg} / \mathrm{hr}$

$$
\text { Mass intensity of RO }=\frac{60000 \mathrm{~kg} / \mathrm{hr}}{57604 \mathrm{~kg} / \mathrm{hr}}=1.042
$$

Total waste $(\mathrm{kg})=1000 \mathrm{~kg} / \mathrm{m}^{3} \times 2.5938 \mathrm{~m}^{3} / \mathrm{hr}=2593.8 \mathrm{~kg} / \mathrm{hr}$

Waste intensity of RO $=\frac{2593.8 \mathrm{~kg} / \mathrm{hr}}{57604 \mathrm{~kg} / \mathrm{hr}}=0.045$

Total mass used in the process $(\mathrm{kg})=60000 \mathrm{~kg} / \mathrm{hr}$

Mass of the product $(\mathrm{kg})=57623 \mathrm{~kg} / \mathrm{hr}$

Mass intensity of MD $=\frac{60000 \mathrm{~kg} / \mathrm{hr}}{57623 \mathrm{~kg} / \mathrm{hr}}=1.041$

Total waste $(\mathrm{kg})=1000 \mathrm{~kg} / \mathrm{m}^{3} \times 2.377 \mathrm{~m}^{3} / \mathrm{hr}=2377 \mathrm{~kg} / \mathrm{hr}$

Waste intensity of MD $=\frac{2377 \mathrm{~kg} / \mathrm{hr}}{57623 \mathrm{~kg} / \mathrm{hr}}=0.041$

Mass intensity ratio $=\frac{1.041}{1.042}=0.9990$

Waste intensity ratio $=\frac{0.041}{0.045}=0.9111$

Productivity/size ratio $=\frac{\left(\frac{60}{37.152}\right)}{\left(\frac{60}{37.185}\right)}=1.00089$

Productivity/weight ratio $=\frac{\left(\frac{60}{16,200}\right)}{\left(\frac{60}{15,000}\right)}=0.925$

Flexibility $=\frac{0.9 \mathrm{bar}}{11 \mathrm{bar}}=0.0818$

Flexibility $=\frac{20^{\circ} \mathrm{C}}{17^{\circ} \mathrm{C}}=1.176$

Flexibility $=\frac{49999.99 \mathrm{mg} / \mathrm{L}}{39259.98 \mathrm{mg} / \mathrm{L}}=1.273$

$$
\begin{gathered}
\text { Flexibility }=\frac{2}{1}=2 \\
\text { Modularity }=\left|\frac{10-10}{10-10}\right|=0
\end{gathered}
$$

Table 11 Adopted results of process intensification metrics calculations for RO and MD desalination plant

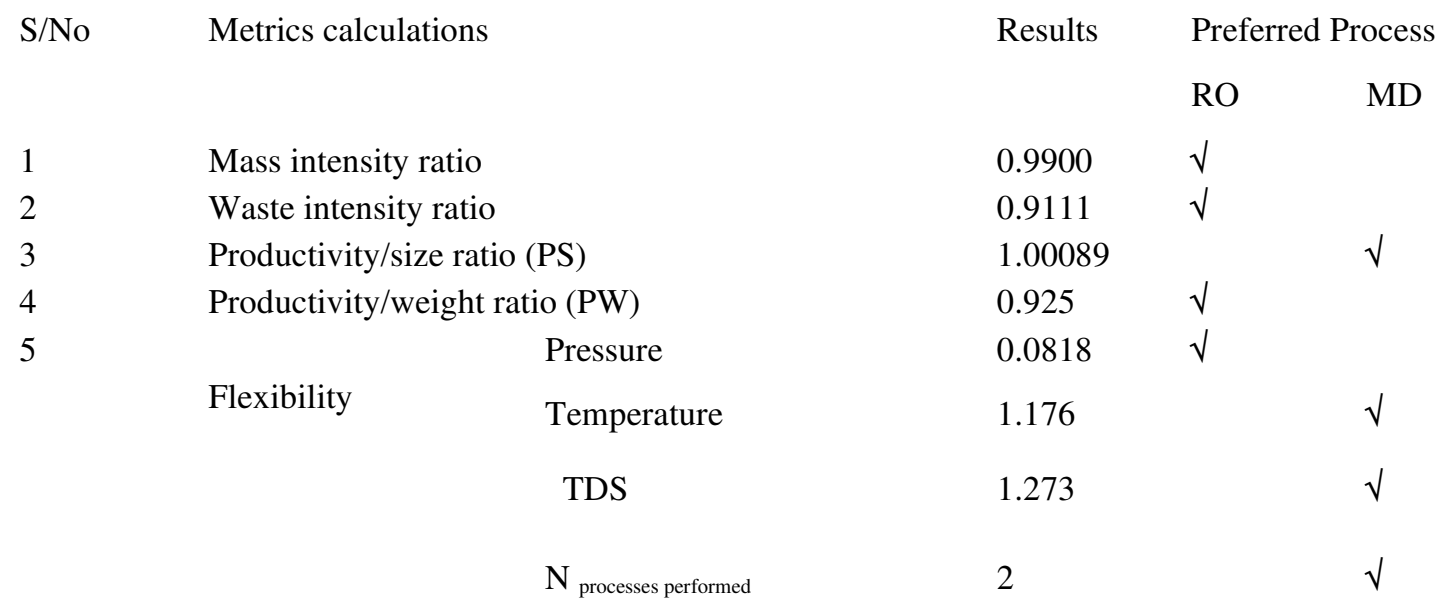




\section{Cost estimation and process economic:}

A comparative method used to compare between technologies based on cost estimation and profits. We evaluated desalinations plant used RO and MD system to desalinate seawater in Oman.

Desalination plant by using RO system:

According to Alibaba.com, (2020), we originated out the overall cost of the machinery required for the building of the desalination plant by using RO system. The equipment price, as shown in the table 12 .

Table 12 The equipment price of the desalination plant by using RO system

$\begin{array}{llll}\text { S/No } & \text { Name of equipment } & \text { Quantity } & \text { Price }(\mathrm{OMR}) \\ \text { 1. } & \text { Storage tanks } & 2 & (2,310) \times 2 \\ 2 . & \text { RO module } & 1 & 34,650 \\ \text { 3. } & \text { High pressure pump } & 1 & 3,850 \\ \text { 4. } & \text { Pelton turbine } & 1 & 3,080 \\ \text { 5. } & \text { Pressure filter } & 1 & 770 \\ 6 . & \text { Pump } & 1 & 140.525 \\ 7 . & \text { Total of Purchased Equipment Costs } & & 47,110.525\end{array}$

Desalination plant by using MD system:

According to Alibaba.com, (2020) and Dijkstra, J. (2019), we found out the overall cost of the equipment required for the building of the desalination plant by using MD system. The equipment price, as shown in the table 13 .

Table 13 The equipment price of the desalination plant by using MD system

$\begin{array}{llll}\text { S/No } & \text { Name of equipment } & \text { Quantity } & \text { Price }(\mathrm{OMR}) \\ 1 & \text { Storage tanks } & 2 & (2,310) \times 2 \\ 2 & \text { MD module } & 1 & 111,769.54 \\ 3 & \text { Heat exchangers } & 2 & (385) \times 2 \\ 4 & \text { Pumps } & 2 & (140.525) \times 2 \\ \text { Total of Purchased Equipment Costs } & & 117,440.59\end{array}$

Regarding to cost estimation and process economic calculation, the below table shows adopted results for RO and MD desalination plant.

Table 14 Adopted results of cost estimation and process economic calculation for RO and MD desalination plant

$\begin{array}{llll}\text { S/No } & \text { Cost estimation and process economic calculation } & \text { RO (OMR) } & \text { MD (OMR) } \\ 1 & \text { Fixed capital investment (FCI) } & 224336 & 559241 \\ 2 & \text { Total capital investment (TCI) } & 280420 & 699051 \\ 3 & \text { Working capital investment (WCI) } & 56084 & 139810 \\ 4 & \text { Total product cost (TPC) } & 61251 & 152692 \\ 5 & \text { Total profits (Before tax) } & 1082550 & 168140 \\ 6 & \text { Total profits (After tax) } & 920167 & 142919 \\ 7 & \text { Total cash flow (Aj) } & 962227 & 247779\end{array}$


Table 15 Adopted results of Cumulative cash flow plot for RO and MD desalination plant

RO

MD

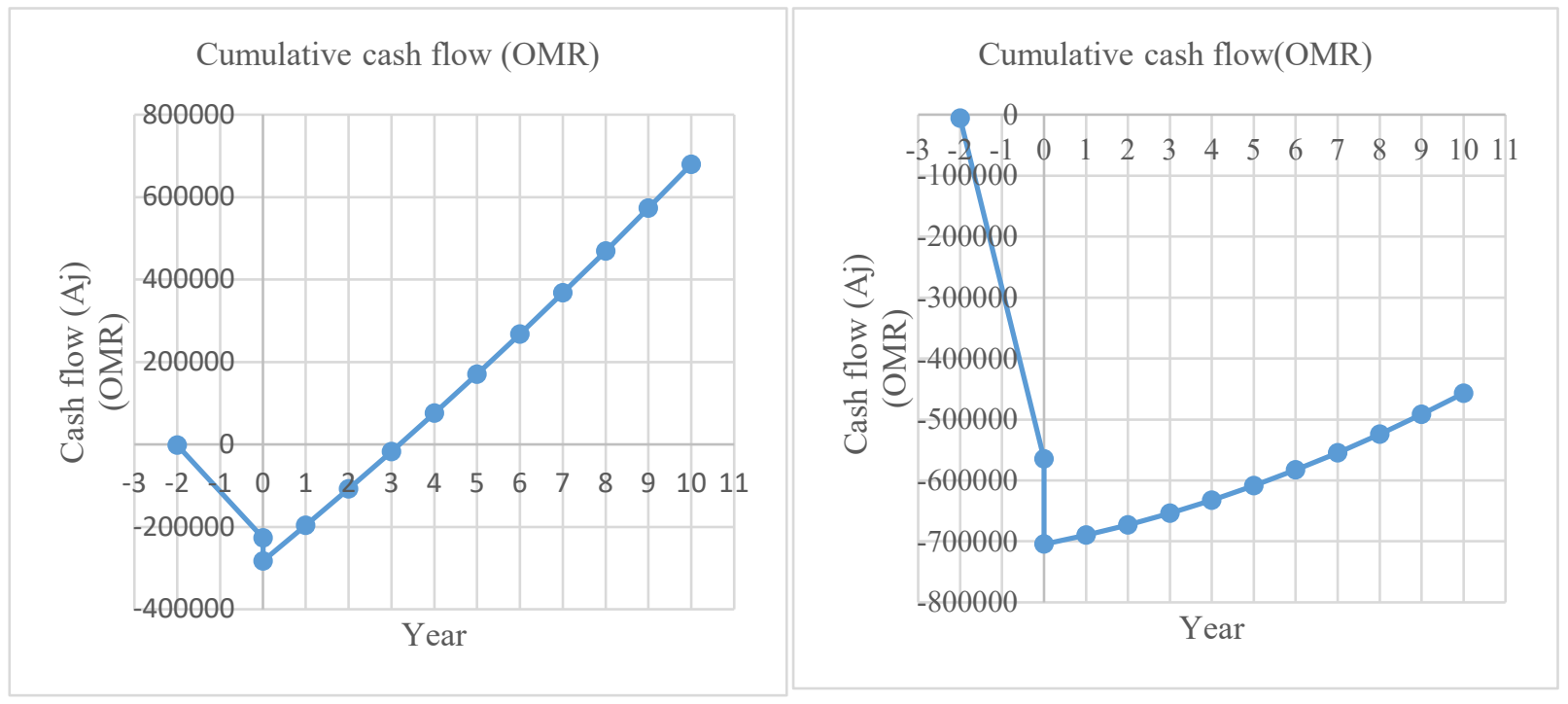

\section{Conclusion}

The performances of two membrane techniques (RO and $\mathrm{MD}$ ) were evaluated for seawater desalination based on the process intensification approach. It was observed that the mass intensity, waste intensity, productivity/weight ratio and pressure flexibility results showed that RO unit is better than the MD unit. On the other hand, the results obtained for the productivity/size ratio, the temperature flexibility, TDS and Number of process performed revealed that the MD unit is better than RO unit. The results of the modularity showed that both units are of equal preference in water desalination. On a general note, the results obtained showed both techniques as competitive water desalination techniques which can be used depending on the existing circumstance.

Based on the cost estimation and process economic calculations, the results of the cost estimation and process economic calculations showed a preference for RO desalination plant than MD desalination. This is because MD is a modern technology and there is presently no competition in manufacturing its module. It was observed that the major cost of MD was from the module. Therefore, the MD cost is very high compared with RO technology. Consequently, the cumulative cash flow plot for RO and MD desalination plant showed that the total capital investment (TCI) of RO can be entirely repaid after 3 years and 2 months whereas the cumulative cash plot of MD showed that the total capital investment (TCI) of MD is cannot be repaid within 10 years. This work has provided insight into the comparative analysis of MD which a relatively new water desalination technology compared to RO.

\section{Acknowledgments}


We would like to thank staff Barka II Power and Desalination plant and Barka III Power plant for their assistance with the collection of our data. All thanks and appreciation for Majis Industrial Service for their support.

\section{References}

Anon. (1996). Development of Revers Osmosis memebrane process for advanced treatement of waste water. Aydiner, C., Imer, D. Y. K., Oncel, S., Dogan, E. C., Narci, A. O., Cakmak, S., Yilmaz, T. N., Celebi, E. E., \& Tilki, Y. M. (2017). Marmara Seawater Desalination by Membrane Distillation: Direct Consumption Assessment of Produced Drinking Water. Desalination, August. doi: 10.5772/intechopen.68653

Constable, D. J. C., Curzons, A. D., \& Cunningham, V. L. (2002). Metrics to 'green' chemistry - Which are the best? Green Chemistry, 4(6), 521-527. doi: 10.1039/b206169b

Criscuoli, A., \& Drioli, E. (2007). New metrics for evaluating the performance of membrane operations in the logic of process intensification. Industrial and Engineering Chemistry Research, 46(8), 2268-2271. doi: 10.1021/ie0610952 Drioli, E., Ali, A., \& Macedonio, F. (2017). Membrane operations for process intensification in desalination. Applied Sciences (Switzerland), 7(1). doi: 10.3390/app7010100

DuPont. (2020). FilmTec ${ }^{\text {TM }}$ SW30XLE-400 Element. 45, 1-3. Retrieved from www.dupont.com/water/contact-us

Fard, A. K., \& Manawi, Y. (2014). Seawater desalination for production of highly pure water using a hydrophobic ptfe membrane and direct contact membrane distillation (DCMD). International Journal of Environmental, Chemical, Ecological, Geological and Geophysical Engineering, 8(6), 398-406.

PDO. (2012). Un Bottled Drinking Water.

Serve, I. W., \& Do, W. W. (2015). Seawater Reverse Osmosis Plant for India's First 4, 000 MW Ultra Mega Power Project. 1-5.

Sharqiyah, D. (2005). Sur Desalination Plant. 2010(18 August), 2.

Ma, J. (2020). Source chemical industry equipment-source Chemical Industry Equipment Manufacturers, Suppliers and Exporters on Alibaba.comGeneral industrial equipment. Retrieved November 11, 2020, from Alibaba.com website: https://www.alibaba.com/

T.K.KIM. (2013). Al Suwadi Power Company SAOC Sultanate of Oman Tractebel Engineering Barka 3 Independent Power Plant. 